\title{
Rethinking of the Overall Planning for Urban and Rural Residents' Medical Insurance System
}

\author{
Linnan Cui \\ School of Literature, Law and Economics \\ Wuhan University of Science and Technology \\ Wuhan, China 430065
}

\begin{abstract}
The overall planning for urban and rural residents' medical insurance system is the basic way to meet the needs of urban and rural residents' survival and development, also an important guarantee for "the overall planning for urban and rural development". Now the overall planning for urban and rural residents' medical insurance system (namely, unifying new rural endowment insurance and urban residents insurance) becomes the direction of national policy and carries out exploration and practice in the country. This paper carries out analysis and exploration from the necessity of overall planning for urban and rural residents' medical insurance system, problems, new problems faced by the unified system, path to realize the system integration and other problems, so as that our country can better realize the integration of urban and rural medical security system, promote the coordinated development of urban and rural society and economy.
\end{abstract}

Keywords-basic medical insurance; urban and rural integration; connection

\section{INTRODUCTION}

In 1998, the basic medical insurance system for urban workers was established in China. In 2003, China began to implement the new rural cooperative medical system in rural areas. In 2007, the urban residents' medical insurance reform pilot started. So far, China has formed the basic medical insurance system covering all the urban and rural citizens in urban and rural areas with urban workers basic medical insurance, urban residents basic medical insurance, new rural cooperative medical care as the main body. This marks that China initially realizes the basic medical insurance "system full coverage", and gradually to "the national medical insurance".

However, due to the existence of system segmentation, system fragmentation, supporting hospital with medicine and other issues, the three systems has not effectively solved the problem of difficult and expensive medical treatment. The overall system integration is the internal demand to achieve social fairness and the urgent need to improve the efficiency. Urban and rural residents' medical insurance system due to the proximity of system model becomes the first step to balance the medical insurance system. Today, the overall planning for urban and rural residents' medical insurance system (namely, unifying new rural endowment insurance and urban residents insurance) becomes the direction of national policy and carries

* Linnan Cui, Master candidate of Wuhan University of Science and Technology. out exploration and practice in the country.

\section{THE NECESSITY OF THE OVERALL PLANNING FOR URBAN AND RURAL RESIDENTS' MEDICAL INSURANCE SYSTEM}

\section{A. Fair Orientation}

The segmentation running of urban and rural medical insurance system is not fair or efficient. The new cooperative medical system mainly takes the county level overall planning, while the urban residents' medical insurance system mainly takes the city-level overall planning. The low level of overall planning and small range of risk sharing, is not conducive to the realization of social mobility of staff, the promotion of social integration, also not conducive to the law of large numbers and social mutual aid as a way to spread the risk. In a certain extent it solidifies the existing urban and rural dual structure and social stratum structure, which becomes the obstacle of a unified labor market. The current situation of the separation of urban and rural residents' medical insurance makes the social security system's income redistribution function distort, and increase the gap between the rich and the poor which leads to reverse distribution. The difference of medical insurance system leading to the "reverse distribution" situation of social medical insurance in the income distribution, namely the transition from the low income to the high income, causes damage to the social equity.

\section{B. Efficiency Orientation}

The management efficiency of segmentation management of urban and rural medical insurance system is not high. The social security management organizations manage the medical insurance for urban residents, the health departments is responsible for the rural cooperative medical care, which have different management measures, independent network management system, different medical insurance drugs directory, unshared insurance and compensation information, leading to the repeated insurance and investment of finance, the increase of cost of management and operation. The decentralization of the management departments makes the problem of the transfer of medical insurance relationship more and more serious. This does not conform to the orientation to achieve the high efficient operation of social security system. 


\section{Policy Orientation}

Diversification of urban and rural residents' medical insurance system hindered the realization of the goal "everybody can enjoy equitable access to basic medical security". The country's strategy to promote the equalization of basic public services enables the realization of the unity of urban and rural medical insurance system to become the due righteousness, and the accelerating process of urbanization makes the integration of economic, social and urban and rural development become an inevitable trend. Under the national policy guidance and macro social trend, the overall planning for urban and rural residents' medical insurance system is conducive to promoting the equalization of basic public services in the connotation and essence, so as to make the large-scale population flow under the background of urbanization free from diseases of worries.

\section{The Basis of the System Model}

The new rural cooperative medical system and urban residents insurance have a similar system. As shown in "Table I', the coverage of the population, the principle of insurance, financing methods of the new rural cooperative medical system and urban residents medical insurance are the same, the security level has no big difference. Although there are many differences in the overall level, management institutions, serious illness insurance, but as long as the proper handling of the integration of organizational institutions, the difficulty of the integration of the system and the resistance will be smaller.

TABLE I. ThE MEDICAL SECURITY SYSTEM OF URBAN AND RURAL RESIDENTS AND ITS INSTITUTIONAL STRUCTURE

\begin{tabular}{|l|l|l|}
\hline & $\begin{array}{l}\text { Urban Residents' Medical } \\
\text { Insurance System }\end{array}$ & $\begin{array}{c}\text { New Rural } \\
\text { Cooperative Medical } \\
\text { Care System }\end{array}$ \\
\hline $\begin{array}{l}\text { Coverage of } \\
\text { the population }\end{array}$ & $\begin{array}{l}\text { All urban non employed } \\
\text { residents }\end{array}$ & Rural residents \\
\hline $\begin{array}{l}\text { The principle } \\
\text { of insurance } \\
\text { participation }\end{array}$ & Voluntary participation & Voluntary participation \\
\hline $\begin{array}{l}\text { Financing } \\
\text { methods }\end{array}$ & $\begin{array}{l}\text { Family payment + financial } \\
\text { subsidies, 320 yuan }\end{array}$ & $\begin{array}{l}\text { Individual family) } \\
\text { participation + financial } \\
\text { subsidies, 320 yuan }\end{array}$ \\
\hline $\begin{array}{l}\text { Security range } \\
\text { The level of } \\
\text { overall } \\
\text { planning }\end{array}$ & $\begin{array}{l}\text { Inpatient and outpatient } \\
\text { medical expenses }\end{array}$ & $\begin{array}{l}\text { Large medical expenses } \\
\text { and hospitalization }\end{array}$ \\
\hline $\begin{array}{l}\text { Management } \\
\text { institutions }\end{array}$ & $\begin{array}{l}\text { Department of Human } \\
\text { Resources and Social } \\
\text { Security }\end{array}$ & \begin{tabular}{l} 
The county level \\
\hline $\begin{array}{l}\text { Serious } \\
\text { illness } \\
\text { insurance }\end{array}$
\end{tabular} Define the serious illness \\
according to the cost & $\begin{array}{l}\text { Define the serious illness } \\
\text { according to disease } \\
\text { species }\end{array}$ \\
\hline
\end{tabular}

III. The PROBLEMS FACED BY THE OVERALL PLANNING FOR URBAN AND RURAL RESIDENTS' MEDICAL INSURANCE SYSTEM

\section{A. The Difference of Personal Financing Methods and Standards}

The average financial subsidies are basically the same, the difference of average financing levels is not large, but the personal financing methods and standards are different. The new rural cooperative medical system with the family as a unit for the overall insured (family bundled insured), implements a unified personal payment standard, which is only around 50 yuan. The family overall insured of the new rural cooperative medical system leads to repeated payment and financial subsidies. The urban residents' medical insurance with the individual insured, sets different payment standards in accordance with different population, mainly divided into two groups - students, children and adults, the average payment of more than 100 yuan. In addition, many places set different payment standards for the elderly, college students, to form four payment grades from low to high as the elderly, adults, students and children, college students.

\section{B. The Difference of Treatment Range and Security Level}

One is the large gap between the reimbursement directory. For the drug directory which can be reimbursed, the new rural cooperative medical system has about 1100 kinds, the urban medical insurance has 2400 kinds, that the latter is two times the former. Two is the gap between the reimbursement ratio and the cap line. For the hospitalization in the medical institutions at the same level, the reimbursement ratio of urban residents is higher than that of rural residents. The reason is that: (1) due to the limit of seeking treatment outside the county and the impact of the low reimbursement ratio of seeking treatment outside the county, rural residents enjoy more medical services of the township hospital and county hospital. (2) The disposable income of urban residents is much higher than the net income of rural residents, resulting in the big gap between the reimbursement top lines based on these two incomes (6 times the income). (3) The outpatient serious illness species and treatment levels are different. The number of outpatient serious illness species of most of the local urban residents' medical insurance is much more than that of the new rural cooperative medical system, and the proportion of reimbursement and reimbursement limit is also significantly higher than that of the new rural cooperative medical system.

\section{The Different Levels of Overall Planning}

First, in the fund overall planning. Medical insurance for urban residents takes the city as a whole; the new rural cooperative medical system has been the county overall planning, with the unified payment, treatment just inside the county, so that there are differences in fund-raising, treatment between the county and the county. The medical treatment outside the county belongs to the remote medical treatment which needs approval and referral, and remote medical treatment level tends to be significantly lower that that in the local. Second, in handling management. The fund management, payment, medical service supervision and management, and other core handing businesses of urban residents medical insurance belongs to the municipal handling institutions, while the county handling institutions take charge of the new rural cooperative medical system.

\section{The Different Management Institutions}

The management of urban residents' medical insurance belongs to the Department of the Human Resources and Social 
Security, while the management of new rural endowment insurance belongs to the Ministry of health. Department interest segmentation results in the situation that in the system integration, urban residents' medical insurance is reluctant to be under the management of the Ministry of Health, while the new rural endowment insurance is reluctant to be under the management of the Human Resources and Social Security. The department interests become obstacles to the unification of urban and rural residents' medical insurance system. In practice and exploration, there is a phenomenon that the medical insurance system of urban and rural residents is unified but the administrative agency is not unified.

\section{E. The Different Reimbursement Basis of Serious Illness Insurance}

Urban residents' medical insurance defines serious illness according to the expense, which includes the medical expense exceeding a certain standard (deductible) into the reimbursement range of serious illness insurance, and generally the reimbursement range is limited within the scope of the policy (the medical insurance directory). The new rural cooperative medical system defines serious illness according to the illness species, which has included 20 kinds of serious illness into the payment range of serious illness insurance to give higher reimbursement treatment than the common illness, and the reimbursement range can break through the medical insurance directory (i.e. the so-called compliance costs). The funding of serious illness insurance directly from the basic insurance, should follow the principle of fairness and basic security. The new cooperative medical system to define serious illness according to illness species does not conform to the principle of fairness of the social insurance, which is not fair to the patients who have high cost diseases other than the listed species. While the reimbursement range breaks through the medical insurance directory, also breaks through the government's responsibility scope of "basic security", leading to the universal tendency of welfare.

\section{THE NEW PROBLEMS AFTER THE OVERALL PLANNING FOR URBAN AND RURAL RESIDENTS; MEDICAL INSURANCE SYSTEM}

\section{A. Leading to the Reduction of Rural Outpatient Reimbursement Patients and the Upward Concentration of Medical Resources}

The integration of urban and rural residents' medical insurance system has weakened the rural primary health service system, so that the medical resources and patients more flow to the city level. Taking Tongling County for example, Tongling County has implemented the combination of medical insurance since May 1, 2013, and the whole city gradually has unified the fund management, financing time, reimbursement treatment, drugs directory, medical management, information platform and the name of the institution, which effectively curbed the problems of repeated insurance participation, reimbursement and government's repeated matching. As shown in "Table II", "Table III", "Fig. IV", "Table V", "Table VI", the combination of Tongling County medical insurance for urban and rural residents also led to the reduction of rural outpatient reimbursement patients $(-67.10 \%)$, the decline of township hospitals inpatients $(-29.69 \%)$, the rise of average hospitalization expenses $(+15.91 \%)$, the reduction of hospitalization actual compensation ration and other problems. The overall planning for urban and rural residents' medical insurance system does not achieve the goal of strong base level.

TABLE II. The SituAtion CHANGE OF RURAL ORDINARY OUTPATIENT PATIENTS AT DIFFERENT LEVELS BEFORE AND AFTER THE INTEGRATION OF MEDICAL INSURANCE IN TONGLING COUNTY

\begin{tabular}{|c|c|c|c|c|c|}
\hline \multirow{2}{*}{$\begin{array}{c}\text { Name of } \\
\text { Organizatio } \\
n\end{array}$} & \multicolumn{2}{|c|}{ In 2012} & \multicolumn{3}{|c|}{ In 2013} \\
\hline & $\begin{array}{l}\text { Outpatient } \\
\text { (person- } \\
\text { time) }\end{array}$ & $\begin{array}{c}\text { Constituent } \\
\text { ratio } \\
(\%)\end{array}$ & $\begin{array}{l}\text { Outpatient } \\
\text { (person- } \\
\text { time) }\end{array}$ & $\begin{array}{c}\text { Constituent } \\
\text { ratio } \\
(\%)\end{array}$ & $\begin{array}{c}\text { Rate of } \\
\text { increase } \\
(\%)\end{array}$ \\
\hline $\begin{array}{l}\text { Village } \\
\text { health center }\end{array}$ & 326976 & 71.97 & 111950 & 74.90 & -65.76 \\
\hline $\begin{array}{l}\text { Township } \\
\text { health center }\end{array}$ & 127348 & 28.03 & 37509 & 25.10 & -70.55 \\
\hline Total & 454324 & 100.00 & 149459 & 100.00 & -67.10 \\
\hline
\end{tabular}

TABLE III. The Situation CHANGE OF HosPitalization PATIENTS AT DIFFERENT LEVELS BEFORE AND AFTER THE INTEGRATION OF MEDICAL INSURANCE IN TONGLING COUNTY

\begin{tabular}{|c|c|c|c|c|c|}
\hline \multirow{2}{*}{$\begin{array}{c}\text { Hospital } \\
\text { Level }\end{array}$} & \multicolumn{2}{|c|}{ In 2012} & \multicolumn{3}{|c|}{ In 2013} \\
\hline & $\begin{array}{c}\text { Hospitalizatio } \\
\text { n (person- } \\
\text { time) }\end{array}$ & $\begin{array}{c}\text { Constituent } \\
\text { ratio } \\
(\%)\end{array}$ & $\begin{array}{c}\text { Hospitalization } \\
\text { (person-time) }\end{array}$ & $\begin{array}{c}\text { Rate of } \\
\text { increase } \\
(\%)\end{array}$ & $\begin{array}{c}\text { Constituent } \\
\text { ratio } \\
(\%)\end{array}$ \\
\hline Township & 2422 & 12.85 & 1703 & -29.69 & 8.10 \\
\hline $\begin{array}{l}\text { County } \\
\text { level }\end{array}$ & 6991 & 37.10 & 7484 & 7.05 & 35.59 \\
\hline City level & 8040 & 42.66 & 10123 & 25.91 & 48.14 \\
\hline $\begin{array}{l}\text { Outside } \\
\text { the city }\end{array}$ & 1392 & 7.39 & 1717 & 23.35 & 8.17 \\
\hline Total & 18845 & 100.00 & 21027 & 11.58 & 100.00 \\
\hline
\end{tabular}


TABLE IV. ThE SituATION CHANGE OF HoSPITALIZATION EXPENSES AT DifFERENT LEVELS BEFORE AND AFTER THE INTEGRATION OF MEDICAL INSURANCE IN TONGLING COUNTY

\begin{tabular}{|c|c|c|c|c|c|c|c|c|}
\hline \multirow{2}{*}{$\begin{array}{c}\text { Hospital } \\
\text { Level }\end{array}$} & \multicolumn{4}{|c|}{ In 2012} & \multicolumn{4}{|c|}{ In 2013} \\
\hline & $\begin{array}{c}\text { Total medical exper } \\
\text { (10000 yuan) }\end{array}$ & $\begin{array}{c}\text { Constituent ratio } \\
(\%)\end{array}$ & $\begin{array}{c}\text { Average cost } \\
\text { (yuan) }\end{array}$ & $\begin{array}{c}\text { Total medical expenses } \\
(10000 \text { yuan })\end{array}$ & $\begin{array}{c}\text { Sate of increase } \\
(\%)\end{array}$ & $\begin{array}{c}\text { Constituent } \\
\text { ratio }(\%)\end{array}$ & $\begin{array}{c}\text { Average cost } \\
\text { (yuan) }\end{array}$ & $\begin{array}{c}\text { Rate of increase } \\
(\%)\end{array}$ \\
\hline Township & 342.58 & 3.35 & 1414.45 & 265.12 & -22.61 & 2.01 & 1556.78 & 10.06 \\
\hline $\begin{array}{l}\text { County } \\
\text { level }\end{array}$ & 2835.77 & 27.75 & 4056.32 & 3206.63 & 13.08 & 24.27 & 4284.65 & 5.63 \\
\hline City level & 4923.96 & 48.19 & 6124.33 & 7118.87 & 44.58 & 53.87 & 7032.37 & 14.83 \\
\hline $\begin{array}{l}\text { Outside } \\
\text { the city }\end{array}$ & 2114.87 & 20.70 & 15193.03 & 2623.41 & 24.05 & 19.85 & 15279.03 & 0.57 \\
\hline Total & 10217.18 & 100.00 & 5421.69 & 13214.03 & 29.33 & 100.00 & 6284.32 & 15.91 \\
\hline
\end{tabular}

TABLE V. The Situation CHANGE of HosPitAlization EXPENSES AT DifFERENT LEVELS BEFORE AND AFTER THE INTEGRATION OF MEDICAL INSURANCE IN TONGLING COUNTY

\begin{tabular}{|c|c|c|c|c|c|c|c|c|c|c|c|}
\hline \multirow{2}{*}{$\begin{array}{c}\text { Hospital } \\
\text { Level }\end{array}$} & \multicolumn{5}{|c|}{ In 2012} & \multicolumn{6}{|c|}{ In 2013} \\
\hline & $\begin{array}{c}\text { Total cost of } \\
\text { compensation } \\
(10000 \text { yuan) }\end{array}$ & $\begin{array}{c}\text { Constituent } \\
\text { ratio } \\
(\%)\end{array}$ & $\begin{array}{c}\text { Average } \\
\text { compensation } \\
\text { (yuan) }\end{array}$ & $\begin{array}{c}\text { Compensation } \\
\text { ratio }(\%)\end{array}$ & $\begin{array}{c}\text { Total cost of } \\
\text { compensation } \\
\text { (10000 yuan) }\end{array}$ & $\begin{array}{c}\text { Rate of } \\
\text { increase } \\
(\%)\end{array}$ & $\begin{array}{c}\text { Constituent } \\
\text { ratio }(\%)\end{array}$ & $\begin{array}{c}\text { Average } \\
\text { compensation } \\
\text { (yuan) }\end{array}$ & $\begin{array}{c}\text { Rate of } \\
\text { increase } \\
(\%)\end{array}$ & $\begin{array}{c}\text { Compensation } \\
\text { ratio }(\%)\end{array}$ & $\begin{array}{c}\text { Rate of } \\
\text { increase } \\
(\%)\end{array}$ \\
\hline Township & 264.29 & 4.66 & 1091.21 & 77.15 & 177.32 & -32.91 & 2.57 & 1041.22 & -4.58 & 66.88 & -10.27 \\
\hline $\begin{array}{l}\text { County } \\
\text { level }\end{array}$ & 1804.55 & 31.82 & 2581.25 & 63.64 & 1870.76 & 3.67 & 27.16 & 2499.68 & -3.16 & 58.34 & -5.30 \\
\hline City level & 2646.27 & 46.66 & 3291.38 & 53.74 & 3774.43 & 42.63 & 54.80 & 3728.57 & 13.28 & 53.02 & -0.72 \\
\hline $\begin{array}{l}\text { Outside } \\
\text { the city }\end{array}$ & 955.94 & 16.86 & 6867.39 & 45.20 & 1064.58 & 11.36 & 15.46 & 6200.23 & -9.71 & 40.58 & -4.62 \\
\hline Total & 5671.05 & 100.00 & 3009.31 & 55.51 & 6887.09 & 21.44 & 100.00 & 3275.36 & 8.84 & 52.12 & -3.39 \\
\hline
\end{tabular}

TABLE VI. The Situation Change of HospitalizAtion EXPENSES AT DifFERENT LEVELS BEFORE AND AFTER THE INTEGRATION IN TONGLiNG COUNTY

\begin{tabular}{|c|c|c|c|c|c|c|c|c|}
\hline \multirow{2}{*}{$\begin{array}{c}\text { Hospital } \\
\text { Level }\end{array}$} & \multicolumn{4}{|c|}{ In 2012} & \multicolumn{4}{|c|}{ In 2013} \\
\hline & $\begin{array}{c}\text { Total drug cost (ten } \\
\text { thousand yuan) }\end{array}$ & $\begin{array}{c}\text { Constituent ratio } \\
(\%)\end{array}$ & $\begin{array}{c}\text { Average cost of drugs } \\
\text { (yuan) }\end{array}$ & $\begin{array}{c}\text { Total drug cost (ten } \\
\text { thousand yuan) }\end{array}$ & $\begin{array}{c}\text { Rate of increase } \\
(\%)\end{array}$ & $\begin{array}{l}\text { Constituent } \\
\text { ratio(\%) }\end{array}$ & $\begin{array}{c}\text { Average cost of } \\
\text { drugs (yuan) }\end{array}$ & $\begin{array}{c}\text { Rate of increase } \\
(\%)\end{array}$ \\
\hline Township & 108.68 & 2.86 & 448.72 & 70.43 & -35.20 & 1.47 & 413.56 & -7.83 \\
\hline $\begin{array}{l}\text { County } \\
\text { level }\end{array}$ & 1071.36 & 28.27 & 1532.48 & 1195.77 & 11.61 & 25.03 & 1597.77 & 4.26 \\
\hline City level & 1839.70 & 48.55 & 2288.18 & 2568.62 & 39.62 & 53.75 & 2537.41 & 10.89 \\
\hline $\begin{array}{l}\text { Outside } \\
\text { the city }\end{array}$ & 769.89 & 20.32 & 5530.82 & 943.72 & 22.58 & 19.75 & 5496.33 & -0.62 \\
\hline Total & 3789.63 & 100.00 & 2010.95 & 4778.54 & 26.10 & 100.00 & 2272.57 & 13.01 \\
\hline
\end{tabular}

\section{B. Leading to Reverse Redistribution, the Phenomenon of the} Poor Supporting the Rich, the Rural Supporting the Urban

The allocation of health resources in our country has the problems of heavy in urban and upper body, light in rural and grassroots organizations. The accessibility of the rural medical and health resources is poor, especially reflected in the health technicians, medical institutions and hospital beds, the actual utilization rate of medical service and medical service distance accessibility etc.. After the integration of urban and rural medical insurance system, due to the medical habitats, distance and other reasons, the rural residents' average medical times, average outpatient cost expenditure, average hospitalization cost expenditure are all lower than that of the urban residents, resulting in that higher income people can consume more medical resources. The integration of the two is prone to the reverse redistribution phenomenon of rural residents supporting the urban residents.

\section{THE METHODS TO ACHIEVE THE INTEGRATION OF URBAN AND RURAL RESIDENTS' MEDICAL INSURANCE SYSTEM}

\section{A. Unify the Payment Policy}

Solve the unreasonable and unfair individual payment policy of the urban and rural residents' medical insurance. First of all, change the voluntary insurance premium payment into the compulsory insurance premium payment, to avoid adverse selection of insurance. Secondly, cancel the payment policy of rural residents with the family as a whole, implement the individual payment policy which is the same as that of the urban residents. Thirdly, unify the individual payment standard of urban residents. It is possible to set a unified payment standard for four categories of people with the average method. Fourthly, in the integration of the new rural cooperative medical system and medical insurance for urban residents, according to the differences in the individual payment of urban 
residents' medical insurance and the individual payment of the new rural cooperative medical system, determine whether unify the individual contributions: if the differences in the urban and rural individual contributions is not large, set the unified payment and treatment standards, and implement "one system one grade"; if the gap between the urban and rural individual contributions is big, implement "one system two grades", allowing the rural residents to choose between two grades. Later at the appropriate time gradually transit to "one system one grade", that unify the payment standards and treatment level for all the urban and rural residents.

\section{B. Unify the Medical Insurance Treatment}

The unified medical insurance benefits can come true through medical insurance directory, reimbursement ratio, payment cap line, the range of outpatient serious illness and treatment level. First of all, unify the medical insurance directory, to ensure that the urban and rural residents can enjoy the same medical services. Take the urban medical insurance directory as the main body, appropriately add a part of the reimbursement items of the new rural cooperative medical system which are necessary for the treatment and have significant effect but not included in the urban medical insurance directory, so as to form the new reimbursement directory of urban and rural residents' medical insurance. Secondly, unify the reimbursement ratio and payment cap line. Regarding the payment of "one system one grade" after the system integration, according to the different medical institution levels, the different and discriminating hospitalization reimbursement ratio is set (the highest for health clinics in towns and townships, the lowest for tertiary hospitals). Regardless of urban and rural residents, implement the same reimbursement ratio in the medical institutions at the same level. Regarding the payment of "one system two grades" after the system integration, the reimbursement ratio of the two payment grades can vary, but the gap should not be too large. Cap line should be high but not low, uniformly with the 6 times of urban residents' disposable income as the payment cap line. Thirdly, unify the scope of outpatient serious illness and treatment level. Take the serious illness of urban outpatient as the basis, realize the unification of the outpatient serious illness in the urban and rural. Specifically carry out transition by the method of "one system multi grades".

\section{Unify the Overall Planning Level}

The overall planning level of urban and rural residents' medical insurance system should be the municipal level. In the current situation of urban medical insurance for the municipal level overall planning and the new rural cooperative medical system for the county level overall planning, gradually achieve the municipal level overall planning through the following measures. Firstly, unify the management function of urban and rural medical insurance, implement the unification of the new rural cooperative medical system's financing, treatment policy of the whole city. Secondly, on the basis of the unified policy, promote the overall planning level of the new rural cooperative medical system to the municipal planning, so as to realize the unified management and usage of the new rural cooperative medical system at the municipal level. The management of the new rural cooperative medical system of the municipal level can rely on existing urban medical insurance agencies. Again, integrate the handling and management businesses of the new rural cooperative medical system and urban residents' medical insurance.

\section{Unify the Serious Illness Insurance}

For the approval of serious illness insurance, is it defined by the cost of or the species? To define the serious illness according to the illness species is not in line with the principle of fairness of social insurance, but also does not meet the basic objectives of the national medical insurance. Therefore, it will gradually transit to define the serious illness by the costs. In the early stage of integrating the urban and rural residents' medical insurance system, implement the unified serious illness insurance policy in accordance with costs in urban and rural areas, but also retain the serious illness insurance policy in accordance with illness species of the new rural cooperative medical system. Secondly, after a period of transition, in the case of progressive increase of the treatment level of serious illness insurance in accordance with costs, cancel the serious illness insurance policy in accordance with illness species.

\section{E. Improve the Accessibility of Medical Resources in Rural Areas}

To avoid the upward concentration of medical resources, reverse redistribution of medical insurance and other problems resulted from the integration of urban and rural medical insurance system, it is necessary to rationally allocate the urban and rural medical and health resources, improve the medical level and education level of doctors in rural areas. Through the classification system of diagnosis and treatment, payment per person, the reasonable arrangement of village doctors remuneration attract high level medical personnel to the rural areas, in order to improve the accessibility and quality level of medical and health resources in rural areas, which is the necessary means to avoid reverse redistribution function of medical insurance system for urban and rural residents, but also the due policy to promote the rational allocation of urban and rural medical and health resources.

\section{CONCLUSION}

In summary, the overall planning for urban and rural residents' medical insurance system is a necessary way to improve our medical insurance system, which is both fair and efficient, in conformance with the social and economic development trend in China. However, China's urban and rural economic development is imbalanced, dual urban-rural structure still persist and the medical consumption level of urban and rural residents is much different, so overall planning is less likely to accomplish overnight. We should pay attention and attach importance to the new problems produced during and after the system integration, continue the adjustment and innovation of policies to ensure the smooth merger of system and further to achieve the urban and rural integration of medical insurance system for urban and rural residents and promote social progress and system innovation in China. 


\section{REFERENCES}

[1] Qiu Yulin and Zhai Shaoguo, Duality Three Dimensional Situation and Overall Planing Development Thinking of Urban and Rural Residents' Medical Security System, Henan Social Sciences, the 6th edition, 2009.

[2] Jin Jiang: the Problems and Suggestions Existed in Urban and Rural Residents'Medical Insurance Integration Operation of Tongling County,China Primary Health Care, September 2014.

[3] Peng Haoran, Different Roads Lead to the Same Goal -- the Methods and Key Issues of the Integration of Urban and Rural Residents' Medical Insurance System, China Human Resources and Social Security,the second edition in 2014: 23-24.

[4] Shen Shuguang, the Theory Thinking and Path Plan of the National Basic Medical Insurance System Integration, Xuehai, the first edition in 2014: 52-58.

[5] Wang Zongfan, the Difference and Integration of the New Rural Cooperative Medical System and Residents'Medical Insurance, China's Social Security, the twelve edition in 2014: 73-75.

[6] Zheng Gongcheng, editor in chief,China's Social Security Reform and Development Strategy (Medical Security Volume), Beijing: People's Press, March 2011. 